EDUKACJA MIĘDZYKULTUROWA

\title{
Alicja Hruzd-MatuszczyK
}

\section{Kultura w edukacji międzykulturowej \\ Cieszyn - Ustroń, 24-26 września 2012 roku}

Kultura w edukacji międzykulturowej była przewodnim tematem XVII ogólnopolskiej konferencji naukowej z udziałem gości zagranicznych zorganizowanej przez Zakład Pedagogiki Ogólnej Uniwersytetu Śląskiego w Cieszynie wraz z Wyższą Szkołą Pedagogiczną Związku Nauczycielstwa Polskiego w Warszawie oraz Stowarzyszeniem Wspierania Edukacji Międzykulturowej.

Tym razem organizatorzy pragnęli zwrócić uwagę uczestników na następujące obszary tematyczne:

- międzykulturowość jako kategoria kultury i edukacji,

- badania w edukacji międzykulturowej,

- komunikacja i dialog między kulturami,

- różne oblicza kultury w edukacji międzykulturowej.

Tradycyjnie pierwszy dzień konferencji wszyscy uczestnicy spędzili w Cieszynie. W salach Ratusza Miejskiego zebranych gości przywitał mgr inż. Jan Matuszek (Zastępca Burmistrza Miasta Cieszyna). W imieniu władz Wydziału Etnologii i Nauk o Edukacji w Cieszynie uroczystego otwarcia konferencji dokonał Dziekan - dr hab. Zenon Gajdzica prof. UŚ oraz dr hab. Urszula Szuścik prof. UŚ - Dyrektor Instytutu Nauk o Edukacji Wydziału Etnologii i Nauk o Edukacji w Cieszynie. W imieniu organizatorów uczestników przywitała dr hab. Alina Szczurek-Boruta prof. UŚ - członek Komitetu Naukowego i Organizacyjnego Konferencji. Z ramienia Zarządu Stowarzyszenia Wspierania Edukacji Międzykulturowej głos zabrał prof. zw. dr hab. Zenon Jasiński (Uniwersytet Opolski).

Zanim przystąpiono do merytorycznych obrad, uwaga gości skoncentrowana była na Annie Trefon - studentce Akademii Muzycznej w Katowicach w klasie harfy, która wprowadziła zebranych gości w świat kultury symbolicznej. Uczestnicy z zachwytem wysłuchali koncertu laureatki wielu prestiżowych nagród i wyróżnień (m.in. Międzynarodowego Konkursu Harfowego Reinla w Wiedniu w 2012 roku).

Następnie dr hab. Ewa Ogrodzka-Mazur prof. UŚ odczytała list przesłany przez prof. zw. dr. hab. Tadeusza Lewowickiego skierowany do uczestników 
sesji naukowej. W dalszej części dr hab. E. Ogrodzka-Mazur prof. UŚ oraz dr hab. A. Szczurek-Boruta prof. UŚ podziękowały osobom, które wzięły udział w tworzeniu niezwykłego dzieła - ksiąg pamiątkowych dedykowanych prof. zw. dr. hab. T. Lewowickiemu ${ }^{1}-\mathrm{i}$ jako redaktorki tomów wręczyły autorom niniejszą publikację.

Pierwszą sesję, zatytułowaną Międzykulturowość jako kategoria kultury i edukacji, otwierały dwa wystąpienia wprowadzające. Prof. zw. dr hab. Katarzyna Olbrycht (Uniwersytet Śląski, WEiNoE w Cieszynie) podczas wystąpienia odniosła się do aksjologicznego wymiaru kultury, poddając pod dyskusję wątpliwości dotyczące miejsca kultury w edukacji międzykulturowej, a także międzykulturowości jako wartości kultury i edukacji. Skłoniła zebranych do namysłu nad tym, czy międzykulturowość traktować jako wartości utylitarne czy perfekcyjne?

W kolejnym wystąpieniu prof. zw. dr hab. Z. Jasiński odniósł się do idei edukacji międzykulturowej. Zaprezentował odmienne stanowiska wskazujące na jej aktualną pozycję, które wynikają m.in. z fali krytyki będącej skutkiem wydarzeń na tle narodowościowym oraz kulturowym. Omówił również liczne oddziaływania (np. ideowe, polityczne), którym podlega. Prelegent wskazał istotę międzykulturowości, która powinna osadzać się na wartościach. Prof. zw dr hab. Z. Jasiński przedstawił - jako przykłady edukacji regionalnej - działania podejmowane w środowiskach zróżnicowanych kulturowo na rzecz poznania i pielęgnowania tradycji, a także podkreślił istotę nauki języków obcych jako fundamentu przełamywania stereotypów i poznawania innych kultur.

Ks. prof. dr hab. Marian Nowak (Katolicki Uniwersytet Lubelski) skoncentrował się na poszukiwaniu wątków międzykulturowych w Biblii. Jego postulatem było doprecyzowanie w podejmowanych działaniach pojęć oraz kategorii dotyczących omawianych zagadnień - m.in. kultury i międzykulturowości analizowanych w określonych kontekstach.

Prof. zw. dr hab. Idzi Panic (Uniwersytet Śląski w Katowicach) zwrócił uwagę na historyczne badania dokumentów i prac powstałych dzięki pedago-

1 E. Ogrodzka-Mazur, A. Szczurek-Boruta (red.): Poza paradygmaty. Pedagogika wielostronna. Ksiega pamiątkowa dedykowana Profesorowi Tadeuszowi Lewowickiemu. Tom 1. Cieszyn - Toruń 2012, Wydział Etnologii i Nauk o Edukacji Uniwersytetu Śląskiego, Wydawnictwo Adam Marszałek; A. Szczurek-Boruta, E. Ogrodzka-Mazur (red.): Poza paradygmaty. Pedagogika międzykulturowa. Księga pamiątkowa dedykowana Profesorowi Tadeuszowi Lewowickiemu. T. 2. Cieszyn - Toruń 2012, Wydział Etnologii i Nauk o Edukacji Uniwersytetu Śląskiego, Wydawnictwo Adam Marszałek. 
gom jako wartość pracy historyka. Źródła te umożliwiają analizę rozmaitych wątków - w tym także tych dotyczących międzykulturowości - na przestrzeni wielu lat.

Dr Adela Kożyczkowska (Uniwersytet Gdański) zaprezentowała referat dotyczący kaszubskiej edukacji regionalnej. Podkreśliła istotną rolę pielęgnowania doświadczeń i dorobku przodków w kształtowaniu świadomości regionalnej. W swojej wypowiedzi odniosła się do działań podejmowanych przez Uniwersytet Gdański.

Również wokół zagadnień związanych z wielokulturowością regionu, zakorzenieniem w tradycji i kompetencjami społecznymi poruszała się dr Dorota Misiejuk (Uniwersytet w Białymstoku), która zaprezentowała wyniki swoich badań prowadzonych na Podlasiu.

Szerszy obraz wielokulturowości zaprezentował prof. zw. hab. Wiktor Rabczuk (PEDAGOGIUM w Warszawie), który wskazał na obecność dialogu międzykulturowego na płaszczyźnie działań instytucji europejskich (m.in. UE, UNESCO), podkreślił również jego poliwalentny charakter.

Na tym zakończono pierwszą część spotkania, po której uczestnicy udali się na spacer po znanych i mniej znanych zakątkach Cieszyna. Przewodnikami po wybranych szlakach byli prof. zw. dr hab. Idzi Panic oraz dr Tadeusz Kania (Uniwersytet Śląski, WEiNoE w Cieszynie).

Jak przystało na konferencję poświęconą kulturze, podczas całego spotkania była ona obecna nie tylko w czasie dysput teoretycznych. W drugiej części dnia organizatorzy zaprosili gości na niezwykły spektakl teatralny pt. „Lalka” zagrany po drugiej stronie Olzy - na Scenie Polskiej w Czeskim Cieszynie. Pierwszy dzień konferencji zakończono uroczystą kolacją podczas której - w kuluarach - wciąż podejmowano wątki zainicjowane wystąpieniami prelegentów.

Drugiego dnia konferencji odbyły się trzy panele dyskusyjne. Moderatorami drugiej sesji poświęconej Kulturze w badaniach międzykulturowych byli dr hab. Krystyna M. Błeszyńska prof. SGGW (Szkoła Główna Gospodarstwa Wiejskiego w Warszawie), dr hab. Marta M. Urlińska prof. UMK (Uniwersytet Mikołaja Kopernika w Toruniu) oraz ks. prof. dr hab. M. Nowak.

Dr hab. M. M. Urlińska mówiła o rekonstrukcji widzenia szkoły na Łotwie przez nauczycieli oraz o ich uczestnictwie w kulturze szkoły.

Następnie ks. prof. dr hab. M. Nowak przypomniał o elementarnych zasadach stanowiących podstawę przeprowadzenia badań naukowych. Podkreślił, że należy zdawać sobie sprawę z zasadności podejmowanych badań międzykulturowych. 
Dr hab. Mirosław Sobecki prof. UwB (Uniwersytet w Białymstoku) wyszczególnił kilka bazowych założeń, którym powinny przyświecać badania naukowe oraz ich opis w kontekście zagadnień związanych z kulturą. Przypomniał, że badacz powinien kierować się świadomością, do jakiego ujęcia odwołuje się w tym momencie, i temu podporządkować definicję pojęć. Brak precyzji może prowadzić do niejasności lub wieloznaczności.

Działalność szkół polonijnych na przykładzie Stanów Zjednoczonych omówił prof. zw. dr hab. Józef Kuźma (Krakowska Akademia im. A. Frycza-Modrzewskiego). Wskazał funkcje i zadania szkół polonijnych w zakresie kształtowania świadomości kulturowej i tradycji narodowej młodego człowieka na przykładzie Stanów Zjednoczonych.

Dr hab. Teresa Wilk prof. UŚ (Uniwersytet Śląski w Katowicach) podała w wątpliwość, czy potrafimy jeszcze ze sobą rozmawiać i wskazała na współczesne znaczenie rozmowy i dialogu.

Prof. zw. dr hab. Z. Jasiński pytał, czy gwarę śląską należy traktować jako język? Zaznaczył, że gwara jest wartością, ponieważ dzieci poznają jeszcze jeden kod językowy. Dodatkowo na pograniczach gwara pełni rolę środka komunikacji, który może niwelować konflikty.

Swoje przemyślenia dotyczące gwary śląskiej zaprezentowała dr Agata Rzymełka-Frąckowiak (Uniwersytet Śląski w Katowicach), która przywołała wyniki najnowszego narodowego spisu powszechnego (według deklaracji Ślązacy stanowią największą mniejszość narodową w Polsce). Prelegentka krytycznie odniosła się do zajęć edukacji regionalnej, które nie są realizowane w szkołach. Jako przyczynę takiego stanu rzeczy wskazała m.in. brak nauczycieli przygotowanych do prowadzenia takich zajęć.

Nieco inny kontekst miała wypowiedź dr Jolanty Suchodolskiej (Uniwersytet Śląski, WEiNoE w Cieszynie), która zaprezentowała problematykę jakości życia w kontekście działalności kulturalnej i obcowania z kulturą. Podkreśliła, że jeśli kultura pozwala człowiekowi rozwijać się, to zarazem sprzyja podnoszeniu jakości jego życia.

Doniesienie z badań prowadzonych wśród kobiet w ośrodkach dla cudzoziemców zaprezentowała dr Agata Świdzińska (Uniwersytet Marii Curie-Skłodowskiej w Lublinie). Wśród wniosków można wskazać m.in., że biorące udział w badaniach kobiety funkcjonują w dwóch kulturach jednocześnie. Dr A. Świdzińska badała również wartości, które są przez kobiety odczuwane i uznawane. 
Trzecia sesja dotyczyła problematyki Komunikacji i dialogu między kulturami. Tę część spotkania poprowadzili dr hab. M. Sobecki prof. UwB oraz prof. zw. dr hab. W. Rabczuk.

Wykład wprowadzający dr hab. M. Sobeckiego prof. UwB dotyczył komunikacji międzykulturowej. W prezentacji uwzględnił istotę międzykulturowości, przedstawił również główne bariery w komunikacji. Wskazał dobre praktyki dotyczące przekazu informacji, a także postawił pytanie o przyszłość edukacji międzykulturowej.

Prof. zw. dr hab. W. Rabczuk omówił wątki prowadzonego dyskursu, do których zaliczył ochronę i promowanie tożsamości kulturowej, aktualne koncepcje różnorodności kulturowej oraz dążenie do poszukiwania pomysłów i inicjatyw w dziedzinie fundamentalnych problemów społecznych.

Dr hab. K. M. Błeszyńska prof. SGGW przytoczyła zadania pedagogiki i pedagoga w zakresie działań podejmowanych w społeczeństwie wielokulturowym. Zaakcentowała działania prowadzone $u$ podstaw $-\mathrm{w}$ środowisku lokalnym, dbanie o rozwój kompetencji międzykulturowych oraz kształtowanie wiedzy o innych religiach, które powinny stać się ważnym obszarem działań szkoły.

Dr Jolanta Muszyńska (Uniwersytet w Białymstoku) omówiła problematykę diagnozowania kompetencji międzykulturowych młodzieży na pograniczu. Przedstawiła szeroko zakrojone badania uczniów szkół średnich oraz studentów, które pozwoliły wyróżnić różne typy środowisk i przypisać im kopmetencje w zakresie międzykulturowości.

Ciekawe - nieco odmienne od pedagogicznego - spojrzenie filologa polskiego na nauczanie języka kaszubskiego w szkołach zaprezentowała dr Justyna Pomierska (Uniwersytet Gdański).

Dr Urszula Klajmon-Lech (Uniwersytet Śląski, WEiNoE w Cieszynie) omówiła społeczności internetowe i sposoby ich komunikacji wykorzystujące najnowsze rozwiązania technologiczne.

Ostatni panel Różne oblicza kultury w edukacji międzykulturowej prowadzili dr hab. T. Wilk prof. UŚ oraz prof. zw. dr hab. J. Kuźma.

Wprowadzając w problematykę sesji, prof. zw. dr hab. J. Kuźma wskazał główne tezy dyskusyjne i postulaty kierowane do pedagogów. Natomiast $\mathrm{dr}$ hab. T. Wilk prof. UŚ zaprezentowała zastosowanie kultury i sztuki w edukacji międzykulturowej.

Dr hab. Marek Walancik prof. SWSZ (Śląska Wyższa Zarządzania im. gen. J. Ziętka) w swoim wystąpieniu zaprezentował kulturę sportu, która - przy- 
taczając słowa Jana Pawła II - posługuje się najczytelniejszym językiem na świecie. Odniósł się także do starożytynych doświadczeń sportowych.

O dokonywaniu indywidualnych wyborów religijnych i jego kulturowym kontekście mówiła dr Aniela Różańska (Uniwersytet Śląski, WEiNoE w Cieszynie).

Dr Beata Kozieł (Uniwersytet Śląski, WEiNoE w Cieszynie) wskazała na zagadnienie sfeminizowanej szkoły oraz fakt, że Innym w szkole staje się nie kto inny jak mężczyzna. O konsekwencjach społecznych takiego stanu mówiła, przytaczając wyniki badań.

Edukację międzykulturową na przykładzie działań podejmowanych w węgierskich szkołach zaprezentowała dr Janina Urban (Uniwersytet Śląski, WEiNoE w Cieszynie).

Mgr Agnieszka Niewiara (Śląska Wyższa Zarządzania im. gen. J. Ziętka) skoncentrowała swoją uwagę na obliczu kultury w edukacji międzykulturowej na przykładzie programu Erasmus prowadzonym na Uniwersytecie Śląskim.

Jako ostatnia głos w dyskusji zabrała mgr Natalia Ruman (Uniwersytet Śląski, WEiNoE w Cieszynie), która zaprezentowała folklor w kulturze na przykładzie miasta Pszczyny. Przedstawiła działania podejmowane w mieście oraz pomysły praktykowanych rozwiązań.

Podsumowania i zakończenia konferencji dokonała dr hab. E. Ogrodzka-Mazur prof. UŚ, która podziękowała wszystkim za udział i merytoryczne obrady prowadzone podczas poszczególnych sesji oraz w kuluarach. Zauważyła, że wśród głównych postulatów kończącej się konferencji rysuje się potrzeba międzykulturowego kształcenia aksjologicznego. Realizacja postulatu umożliwi kształtowanie wrażliwości aksjologicznej, a także umożliwi budowanie odpowiedniej postawy. Wskazała, że dostrzegalna staje się potrzeba zmiany stosunku do wielokulturowości. Na tym oficjalnie zamknięto konferencję i zaproszono gości do kontynuowania rozważań obejmujących - szeroko pojmowaną - problematykę kultury w edukacji międzykulturowej. 